\title{
OBSERVATIONS AT BORE HOLES SUNK THROUGH THE SCHUCHERT GLETSCHER IN NORTH-EAST GREENLAND
}

\author{
By G. Kirchner \\ (Ingenieurbüro für Geologie und Bauwesen, Salzburg, Austria)
}

THe Schuchert Gletscher, which is situated in lat. $72^{\circ} \mathrm{N}$. and long. $24^{\circ} \mathrm{W}$., is about $420 \mathrm{~m}$. thick at its confluence with the Arcturus Gletscher. Its total length is about $30 \mathrm{~km}$. In 1958 the measured ablation on the glacier was approximately $3 \mathrm{~m}$. $/ \mathrm{yr}$. The velocity of the glacier is not known, but it is probably very low, and it is believed to be not more than I m./yr. at the Erzbjærg. The edge of the glacier is retreating. Many side glaciers flow into the Schuchert Gletscher.

Bore holes were sunk through the Schuchert Gletscher for the purpose of exploring the possible extension of a body of molybdenum ore. About roo $\mathrm{m}$. from the glacier edge eight holes were drilled through the glacier ice to bedrock. After $100 \mathrm{~m}$. of ice they usually penetrated solid, unfractured biotite-granite, polished by the ground moraine. While drilling through the glacier ice many boulders of different sizes were encountered. These rocks amounted to approximately 6-8 per cent of the total thickness of the glacier. The boulders near the surface of the glacier had come from at least $2 \mathrm{~km}$. up-glacier on the Schuchert Gletscher. The ones lower down in the glacier ice were granite boulders from the Erzbjærg. It was difficult to penetrate the lowest $3 \mathrm{~m}$. of ice immediately adjacent to the bedrock. In general, these last metres consisted of sandy or silty material with about 80 per cent of ice. The flushing water sometimes disappeared completely in this zone, but normally as soon as the bottom of the ice was reached. At the same moment as the bottom was reached quite a strong suction could be noticed and this lasted for some time. Because the water was not lost in every hole, the loss of water in some was accordingly explained by drainage into subglacial channels. However, this assumption may be wrong.

The temperature at the bottom of the glacier is probably very near to $0^{\circ} \mathrm{C}$. This result was obtained by measurements of temperature made inside the mountain. Recent measurements showed a temperature of $+4 \mathrm{C}$. The permafrost in this region is about $220 \mathrm{~m}$. thick, at least in the mountains above the glaciers. At other places nearer the coast the depth of permanently frozen ground or rock is between 80 and $\mathrm{r} 60 \mathrm{~m}$.

The Erzbjærg, which was the subject of our investigation, is a Tertiary intrusion into Carboniferous sediments and post-magmatic activity can still be observed, mainly as carbon dioxide issuing at low pressure (about $40 \mathrm{~cm}$. of water) from joints in the rocks. This gas also came from some of the holes through the ice. Since this occurred when only a few metres had been drilled into the solid granite, it was concluded that there could be no permafrost. The reason for this is that joints in rock beneath the permafrost zone are open, whereas all the others are ice-filled.

In the summer of 1962 water at a temperature of $+4^{\circ} \mathrm{C}$. and a pressure of 6 atmospheres flowed from one hole inside the Erzbjærg. The water pressure decreased quickly but it increased again after some time when the gauge had been shut. This might be a very important observation, because it is believed that the water is not chemically pure and that it came from outside the mountains, i.e. from the Arcturus Gletscher. The following spectrographic analysis on 201 . of water, which was boiled down to 0.41 , , was made by Fresenius of Wiesbaden, Germany.

$\begin{array}{llllll}\mathrm{As}^{+3(+5)} \text { tr } & \mathrm{Zn}^{+2} \text { det } & \mathrm{Be}^{+2} \text { tr } & \mathrm{K}^{+1} \mathrm{tr} \\ \mathrm{Ag}^{+1} & \text { tr } & \mathrm{Fe}^{+2(+3)} \text { det } & \mathrm{Ba}^{+2} \text { det } & \mathrm{Na}^{+1} \text { det } \\ \mathrm{Pb}^{+2} & \text { det } & \mathrm{Mn}^{+2} \text { det } & \mathrm{Sr}^{+2} \text { det } & \mathrm{B}^{+1} \text { det } \\ \mathrm{Cu}^{+2} & \text { det } & \mathrm{Al}^{+3} \text { det } & \mathrm{Ca}^{+2} \text { det } & \mathrm{Si}^{+4} \text { det } \\ \mathrm{Mo}^{+2} & \text { tr } & \mathrm{Ti}^{+4} \text { tr } & \mathrm{Mg}^{+2} \text { det } \\ & & & \\ & & & \end{array}$


In addition to the elements listed above, anions such as carbon dioxide, sulphate and chloride were present in detectable amounts. In our opinion it is likely that this water came from the Arcturus Gletscher but on its way through the mountains it dissolved the cations and became partly mixed with "juvenile" waters containing the anions. The fact that water dissolves cations on its way through the mountains has been proved from many places. The conclusion that the water came from the Arcturus Gletscher is even more emphasized by the fact that the pressure of the water corresponds to the elevation of the Arcturus Gletscher above the drill hole in the adit.

These observations and conclusions lend some support to the theory of catastrophic glacier advances put forward by Weertman (1962).

\section{Acknowledgements}

I wish to thank Dr. J. Weertman for encouraging me to publish my observations, and Cand. Ing. H. Wöber and Dipl. Ing. H. Hintsteiner for making available to me certain of their observations.

MS. received 8 January 1963 and in revised form ${ }_{15}$ February 1963

\section{REFERENCE}

Weertman, J. 1962. Catastrophic glacier advances. Union Géodésique et Géophysique Internationale. Association Internationale d'Hydrologie Scientifique. Commission des. Neiges et Glaces. Colloque d'Obergurgl, 10-9-18-9 1962, p. 3 I-39. 